PRELIMINARY COMMUNICATIONS

\section{Lymphocytotoxins in Leukaemia}

\section{ANN DICKSON}

British Medical fournal, 1972, 4, 209-211

\section{Summary}

Fifteen out of 51 patients with leukaemia have produced a lymphocytotoxin in their serum which reacts with their own and a high percentage of all other lymphocytes. This is probably a protein, but not an antibody. It has been detected only before or early during cytotoxic treatment, or during a relapse. It is postulated that the lymphocytotoxin is a specific protein produced by the leukaemic cells, which may facilitate their spread in the body.

\section{Introduction}

During a study of the immune changes of leukaemia patients two factors have been found in their serum. The first is an autoantibody similar to that discovered by Doré et al. (1967) and Mathe (1970), and the second is a lymphocytotoxin. The lymphocytotoxin was discovered by using the standard cytotoxicity test designed by Terasaki and McClelland (1964) for tissue typing. It gave the cells that it killed an unusual appearance when compared with those cells killed by an antibody under the conditions of this test. In this paper the occurrence of the lymphocytotoxin and the results of the various tests that were carried out to determine its properties are discussed.

\section{Methods}

The cytotoxicity test (Terasaki and McClelland, 1964) was used as the basis of all the investigations, but variations, such as the omission of complement and alterations of the temperature and duration of the test, were introduced to see whether they reduced or increased the numbers of cells killed by the lymphocytotoxin. As usual all sera which killed more than $20 \%$ of the lymphocytes were regarded as positive. HL-A antisera obtained from the N.I.H. at Bethesda, Maryland, were used as controls. Thirty antisera covering HL-A antigens $1,2,3,5,7,8,9,10$, 11,12 , and 13 were subjected to the same tests as the lymphocytotoxins, and comparisons were made between the activity of both test and control sera. Sera from 31 normal individuals and 74 patients with other diseases were screened for lymphocytotoxins. These included patients with other forms of cancer, other haematological diseases, and unrelated diseases such as glandular fever and rubella. Three of these patients were found to have a lymphocytotoxin in their serum, two were patients with a neutropenia, and the third had myeloid metaplasia. All sera including the negative ones were screened against lymphocytes from at least 100 donors.

\footnotetext{
Department of Clinical Haematology, University College Hospital Medical School, London W.C.1 ANN DICKSON, B.sC., Research Assistant
}

Trypsin digestion was carried out by a modification of a standard method (Huehns, 1968); $0.25 \mathrm{ml}$ of se:um was incubated with $0.35 \mathrm{mg}$ of trypsin in $1 \mathrm{ml}$ of $1 / 1,000 \mathrm{~N} \mathrm{HCl}$ at $37^{\circ} \mathrm{C}$ for four hours at $\mathrm{pH} 7 \cdot 0$. In the original method the incubation is carried out at $\mathbf{p H ~} \mathbf{9 . 0}$ for two hours, but in the present experiment it was impossible to raise the $\mathrm{pH}$ to 9.0 as it would have killed the lymphocytes. The lower $\mathrm{pH}$ of this experiment slows the rate of digestion so the incubation time was doubled.

In the ribonuclease digestion experiment $0.025 \mathrm{ml}$ of $1 \%$ aqueous solution of ribonuclease was added to $1 \mathrm{ml}$ of serum. This mixture was incubated at $37^{\circ} \mathrm{C}$ for four hours.

Molecular size was investigated by dialysing aliquots of serum in $t$ in $(6.3 \mathrm{~mm})$ dialysis tubing against phosphate-buffered saline at $\mathrm{pH} 7 \cdot 3$ for 24 hours. One would expect that all substances with a molecular weight of less than about 10,000 would by dialysed out by this method (Craig et al., 1969).

\section{Results}

\section{OCCURRENCE OF LYMPHOCYTOTOXIN}

Fifty-one patients with leukaemia were tested, 25 before or during the first two weeks of treatment, and the lymphocytotoxin was detected in 11. A further eight were tested only in relapse, three of whom had a lymphocytotoxin. As Table I shows, the lymphocytotoxin was found predominantly in patients with

TABLE I-Distribution of Lymphocytotoxin in Relation to Type of Leukaemia

\begin{tabular}{|c|c|c|c|c|c|}
\hline \multirow{2}{*}{\multicolumn{2}{|c|}{ Type of Leukaemia }} & \multicolumn{2}{|c|}{$\begin{array}{c}\text { Before Two Weeks' } \\
\text { Treatment }\end{array}$} & \multicolumn{2}{|c|}{ During Relapse } \\
\hline & & $\begin{array}{l}\text { Total } \\
\text { Tested }\end{array}$ & $\begin{array}{l}\text { No. } \\
\text { Lymphocytotoxin } \\
\text { Positive }\end{array}$ & $\begin{array}{l}\text { Total } \\
\text { Tested }\end{array}$ & $\begin{array}{c}\text { No. } \\
\text { Lymphocytotoxin } \\
\text { Positive }\end{array}$ \\
\hline $\begin{array}{l}\text { Acute myeloid } \\
\text { Chronic myeloid } \\
\text { Acute lymphatic } \\
\text { Chronic lymphatic }\end{array}$ & $\begin{array}{l}\ldots \\
\cdots \\
\cdots\end{array}$ & $\begin{array}{r}10 \\
6 \\
7 \\
2\end{array}$ & $\begin{array}{l}6 \\
4 \\
0 \\
1\end{array}$ & $\begin{array}{l}5 \\
0 \\
2 \\
1\end{array}$ & $\begin{array}{l}3 \\
0 \\
0 \\
0\end{array}$ \\
\hline Total $\quad \ldots$ & $\ldots$ & 25 & 11 & 8 & 3 \\
\hline
\end{tabular}

Eighteen patients were tested only in remission.

One patient with chronic lymphatic leukaemia had a detectable lymphocytotoxin during remission.

myeloid leukaemias. Of the 15 patients with acute myeloid leukaemia tested nine had a lymphocytotoxin, as did four of the six patients with chronic myeloid leukaemia. The other two leukaemia patients with the lymphocytotoxin had chronic lymphatic leukaemia, and in one of these it was found during remission. Although nine patients with acute lymphatic leukaemia were investigated, seven within the first few days of treatment, no lymphocytotoxins were detected in any of them. The remaining 18 patients were tested only during remission.

As cytotoxic treatment proceeded the activity of the lymphocytotoxin was no longer detected (Table II). In two patients, Cases 12 and 13, from whom the first two samples were obtained within a week of each other, the second and post-treatment sample had a weaker activity than the first. In five patients the lymphocytotoxin was detected during relapse. Two of these patients had had a lymphocytotoxin in their serum in the first few days of treatment and two were not tested before their relapse. The fifth patient, although tested early during his disease, had a detectable lymphocytotoxin only during relapse.

All the lymphocytotoxic sera were tested against the patients' own lymphocytes and those from at least 100 donors. In each case it reacted positively with their own lymphocytes and with a 
TABLB II-Occurrence of Lymphocytotoxin in Relation to Treatment

\begin{tabular}{|c|c|c|c|c|c|c|c|}
\hline Case No. & Type of Leukaemia & Before Treatment & 1st Week & 2nd Week & $\begin{array}{l}\text { Samples During Remission or } \\
\text { Partial Remission }\end{array}$ & Relapse & $\begin{array}{l}\text { After Further } \\
\text { Treatment }\end{array}$ \\
\hline $\left.\begin{array}{rr}1 & \\
2 & \\
3 & \\
4 & \\
5 & \\
6 & \\
7 & \\
8 & \\
9 & \\
10 & \\
11 & \\
12 & \\
13 & \\
15 & \{\end{array}\right\}$ & $\begin{array}{l}\text { Acute myeloid } \\
\text { Subacute myeloid } \\
\text { Chronic myeloid } \\
\begin{array}{c}\text { Chronic } \\
\text { lymphatic }\end{array}\end{array}$ & $\begin{array}{l}+ \\
+ \\
+ \\
+ \\
+\end{array}$ & $\begin{array}{l}+ \\
+ \\
+\end{array}$ & $\begin{array}{l}\bar{t} \\
\overline{-} \\
\overline{+} \\
+\end{array}$ & $\begin{array}{l}1 \text { negative in } 2 \text { months } \\
7 \text { negative in } 6 \text { months } \\
13 \text { negative in } 14 \text { months } \\
3 \text { negative in } 5 \text { months } \\
7 \text { negative in } 16 \text { months } \\
8 \text { negative in } 12 \text { months } \\
3 \text { negative in } 11 \text { months } \\
4 \text { negative in } 4 \text { months } \\
2 \text { negative in } 6 \text { months } \\
+\end{array}$ & $\begin{array}{l}+ \\
+ \\
+ \\
+ \\
+\end{array}$ & - \\
\hline
\end{tabular}

TABLB III-Tests for Characterization of Lymphocytotoxin. Results given as Percentage of Cells Killed

\begin{tabular}{|c|c|c|c|c|c|c|c|c|c|c|c|c|c|}
\hline & \multirow{2}{*}{\multicolumn{3}{|c|}{ Case No. }} & \multicolumn{2}{|c|}{$\begin{array}{l}\text { Complement } \\
\text { Dependence }\end{array}$} & \multicolumn{2}{|c|}{$\begin{array}{c}\text { Antihuman IgG } \\
\text { Inhibition }\end{array}$} & \multicolumn{2}{|c|}{$\begin{array}{c}\text { Antihuman IgM } \\
\text { Inhibition }\end{array}$} & \multicolumn{2}{|c|}{$\begin{array}{c}\text { Temperature } \\
\text { Difference }\end{array}$} & \multicolumn{2}{|c|}{$\begin{array}{c}\text { Time } \\
\text { Difference }\end{array}$} \\
\hline & & & & $+\mathrm{C}$ & $-\mathbf{C}$ & + & - & + & - & $4^{\circ} \mathrm{C}$ & $37^{\circ} \mathrm{C}$ & $5 \mathrm{Min}$ & $60 \mathrm{Min}$ \\
\hline 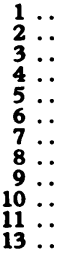 & $\begin{array}{l}\because \\
\because \\
\because \\
\because \\
\because \\
\because \\
\because \\
\cdots\end{array}$ & $\begin{array}{l}\because \\
\because \\
\because \\
\because \\
\because \\
\because \\
\because \\
\therefore\end{array}$ & $\begin{array}{l}\because \\
\because \\
\because \\
\because \\
\because \\
\because \\
\because \\
\therefore\end{array}$ & $\begin{array}{r}30 \\
33 \\
32 \\
31 \\
>95 \\
24 \\
82 \\
20\end{array}$ & $\begin{array}{r}50 \\
56 \\
36 \\
22 \\
>95 \\
21 \\
75 \\
23\end{array}$ & $\begin{array}{r}18 \\
50 \\
50 \\
33 \\
\\
>95 \\
34 \\
50 \\
50\end{array}$ & $\begin{array}{r}47 \\
48 \\
50 \\
25 \\
\\
>95 \\
28 \\
<10 \\
50\end{array}$ & $\begin{array}{r}45 \\
50 \\
50 \\
26 \\
\\
>95 \\
22 \\
<10 \\
75\end{array}$ & $\begin{array}{r}47 \\
48 \\
50 \\
25 \\
\\
>95 \\
28 \\
<10 \\
50\end{array}$ & $\begin{array}{l}20 \\
38 \\
28 \\
\\
80 \\
23 \\
13 \\
30 \\
20 \\
75\end{array}$ & $\begin{array}{r}20 \\
29 \\
25 \\
\\
>95 \\
33 \\
25 \\
25 \\
10 \\
60\end{array}$ & $\begin{array}{r}>95 \\
50 \\
<10 \\
43 \\
>95 \\
>95 \\
>95 \\
44 \\
33 \\
60 \\
>95\end{array}$ & $\begin{array}{r}>95 \\
50 \\
<10 \\
47 \\
>95 \\
>95 \\
>95 \\
41 \\
35 \\
75 \\
>95\end{array}$ \\
\hline \multicolumn{4}{|c|}{ Mean difference \pm S.D. } & \multicolumn{2}{|c|}{$+4.1 \pm 11.05$} & \multicolumn{2}{|c|}{$-3.37 \pm 18.7$} & \multicolumn{2}{|c|}{$-2.5 \pm 9.8$} & \multicolumn{2}{|c|}{$+3.89 \pm 9.8$} & \multicolumn{2}{|c|}{$-1.64 \pm 4.7$} \\
\hline
\end{tabular}

high percentage of the other lymphocytes-for example, serum from Case 6 killed lymphocytes from $96 \%$ of the donors, while that from Case 13 reacted with $82 \%$ of the lymphocytes.

The strength of the lymphocytotoxin was measured by comparing the percentage of lymphocytes killed in each reaction with the donors' cells. This varied greatly between the different sera-for example, Case 6 gave persistently high kills, frequently of over $95 \%$, while Case 5 gave very low kills and sometimes negative results. The serum obtained from any one patient at a given time gives consistent results when tested against a panel of lymphocytes though, as already mentioned, samples collected from the same patient at different stages of their disease gave very different results.

\section{CHARACTERIZATION OF LYMPHOCYTOTOXIN}

Complement Dependence.-Two plates containing nine lymphocytotoxic sera and two control plates were incubated at $37^{\circ} \mathrm{C}$ for one hour with lymphocytes from the same donor. Halfway through the incubation complement was added to one plate of both lymphocytotoxic sera and HI-A antisera. At the end of the hour all four plates were read microscopically. Whereas both plates of lymphocytotoxic sera gave positive results, whether or not complement had been added (Table III), only the control plate with complement was positive. On this plate the donor typed HL-A1, HL-A2, and HL-A8.

IgG and IgM Inhibitions.-Plates containing eight lymphocytotoxic sera and control plates were incubated with either antihuman IgG or antihuman IgM. These sera were subsequently used in the cytotoxicity test together with an unreacted plate of test and control sera. Neither antibody decreased the number of cells killed by the lymphocytotoxin, though both inhibited the activity of the HL-A antisera (Table III).

Temperature Dependence.-Antibodies are normally dependent on a narrow range of temperatures for their activity. In the case of the HL-A antibodies used their optimum temperature was $37^{\circ} \mathrm{C}$. The lymphocytotoxin reacted equally strongly, however, at $4^{\circ} \mathrm{C}$, room temperature, and $37^{\circ} \mathrm{C}$ (Table III).
Incubation Time.-This had little effect on the lymphocytotoxin's activity. Twelve of the sera were incubated for lengths of time varying between five minutes and two hours, and even after five minutes the percentage of dead cells was high (Table III). An hour's incubation was taken as the standard for comparison.

pH Variations.-Lymphocytes are very sensitive to changes in $\mathrm{pH}$ and die if this varies much from 7·3. As a result it proved impossible to evaluate the effect of pH variations in the lymphocytotoxin's activity.

Molecular Size.-The only tests that have been carried out so far to determine the molecular size of the lymphocytotoxin are the dialysis experiments. When the lymphocytotoxic sera that had been dialysed were used in the cytotoxicity test their activity was still present, which suggests that it has a molecular weight of greater than 10,000 (Table IV). As a control normal group $A B$ serum was dialysed and negative results were obtained. TABLB IV-Results of Dialysis Experiments expressed as Percentage of Cell
Killed

\begin{tabular}{c|c|c|c|c}
\hline \multirow{4}{*}{ Cells } & \multicolumn{2}{|c|}{ Serum from Case 7 } & \multicolumn{2}{c}{ Serum from Case 8 } \\
\cline { 2 - 5 } & $\begin{array}{c}\text { After } \\
\text { Dialysis } \\
(\%)\end{array}$ & $\begin{array}{c}\text { Undialysed } \\
(\%)\end{array}$ & $\begin{array}{c}\text { After } \\
\text { Dialysis } \\
(\%)\end{array}$ & $\begin{array}{c}\text { Undialysed } \\
(\%)\end{array}$ \\
\hline 1 & 21 & 19 & 33 & 36 \\
3 & 33 & 33 & 26 & 49 \\
4 & 21 & 30 & 41 & 29 \\
\hline
\end{tabular}

Trypsin Digestion.-The lymphocytotoxic sera that had been digested by trypsin had lost their activity when used in the cytotoxicity test subsequently. As controls neat lymphocytotoxic serum and lymphocytotoxic serum plus $1 \mathrm{ml}$ of $1 / 1,000 \mathrm{~N}$ HC1 were incubated at $37^{\circ} \mathrm{C}$ for four hours, and the activity remained in the sera. Normal serum was subjected to all these tests and remained unaffected (see Chart). As trypsin digested the lymphocytotoxin it is probably a protein. 

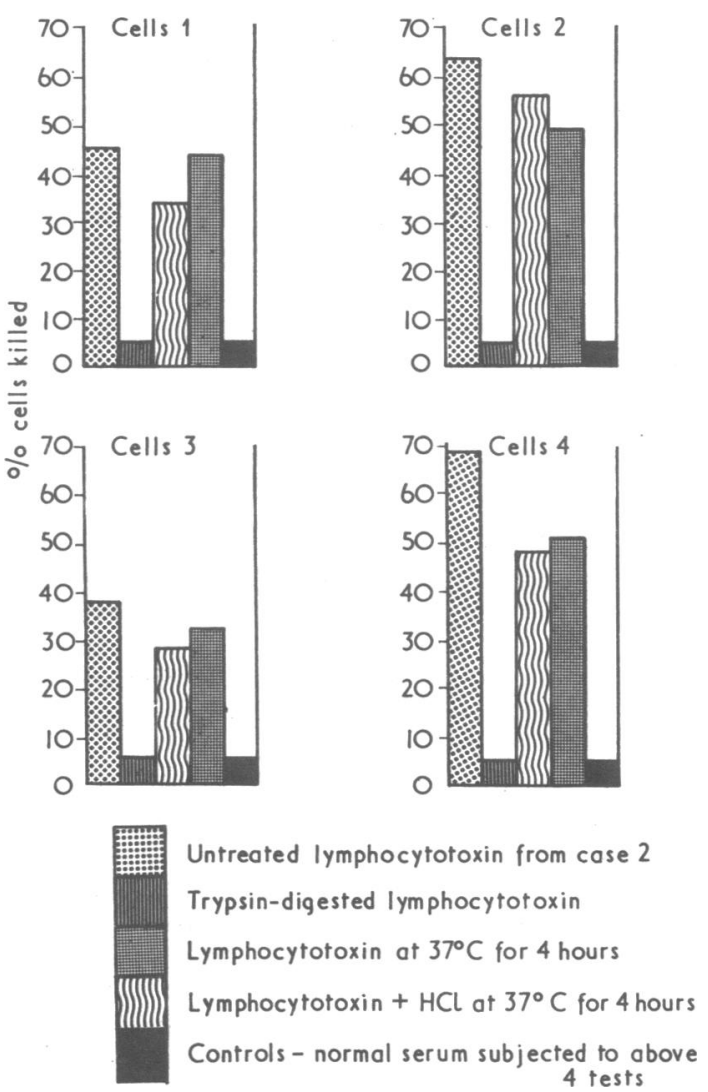

Effect of trypsin digestion on percentage of cells killed.

Ribonuclease Digestion.-The activity was still present in the lymphocytotoxic serum after ribonuclease digestion, showing that it is not ribonucleic acid (Table V).

TABLE v-Ribonuclease Digestion expressed as Percentage of Cells killed

\begin{tabular}{|c|c|c|c|c|c|}
\hline & Cells: & 1 & 2 & 3 & 4 \\
\hline $\begin{array}{l}\text { Lymphocytotoxin } \\
\text { Lymphocytotoxin }+ \text { ribonuclease } \\
\text { Normal serum } \\
\text { Normal serum + ribonuclease }\end{array}$ & $\begin{array}{l}\because \\
\because \\
.\end{array}$ & $\begin{array}{r}38 \\
45 \\
<10 \\
<5\end{array}$ & $\begin{array}{l}39 \\
37 \\
<5 \\
<5\end{array}$ & $\begin{array}{r}42 \\
34 \\
<5 \\
<5\end{array}$ & $\begin{array}{r}43 \\
37 \\
<5 \\
<5\end{array}$ \\
\hline
\end{tabular}

*Serum from Case 8.

\section{Discussion}

The lymphocytotoxin reacts equally strongly with or without complement, its activity is not inhibited by either antihuman IgG or antihuman IgM, and, furthermore, it reacts rapidly and over a wide range of temperatures. These findings are not those of normal antibody activity, indicating that the lymphocytotoxin is not an antibody. The finding that the lymphocytotoxin's activity is not dialysable but is destroyed by digestion with trypsin suggests that it is a protein. There is evidence from comparisons of platelet-free and non-platelet-free lymphocyte suspensions that suggests that the lymphocytotoxin may also react with platelets, but as so far no work has been done with other cells it is impossible to say whether it reacts with a wider range of cells than that suggested by the name lymphocytotoxin.

The lymphocytotoxin is found predominantly in patients with myeloid leukaemia mainly before or during the first two weeks of treatment. After the beginning of treatment the lymphocytotoxin's activity becomes weaker and finally undetectable. This may be because either it is destroyed by cytotoxic drugs or these drugs are destroying the cells that are producing it. In a few patients it has been detected during relapse despite their receiving these drugs.

The problem of what produces the lymphocytotoxin remains. One explanation is that it may be produced by the host in an attempt to eliminate the malignant cells. As it kills normal lymphocytes, including those of the host, this seems unlikely. Moreover one would expect that such a defence mechanism would involve the production of antibodies and, in fact, weak autoantibodies have been found in some patients with leukaemia by Doré et al. (1967), Mathé (1970), and me. If it were a product of the host it would probably be present at all times, whereas this substance is not detectable when the patient is in remission or partial remission.

Another possibility is that it is produced by the leukaemic cells. If this is the case it may be formed in several ways. It may be either a non-specific breakdown product of these cells or a specific antilymphocyte substance. The finding that it is not detectable when the largest number of abnormal cells are being killed-namely, when the patient is receiving cytotoxic treatment-makes it unlikely that the lymphocytotoxin is a breakdown product of leukaemic cells. The findings presented are consistent with the suggestion that the lymphocytotoxin is a specific substance that kills lymphocytes and in this way might inhibit the normal response of the body to foreign cells. This would facilitate the spread of the malignant cells and may be one of the causes of the rapid progress of some leukaemias. It would also explain why it has never been detected in acute lymphatic leukaemia patients, for if they produced a lymphocytotoxin they would be hindering the spread of the cells, not enhancing it. Against this explanation is the failure to detect the lymphocytotoxin whenever there are leukaemic cells present, as when the patient is in incomplete remission. Possibly the lymphocytotoxin is mainly released at the site of production of the cells and is detectable in the peripheral blood only when there is a high turnover of leukaemic cells. Thus it is found in the peripheral blood only before treatment, or during relapse, when there are large numbers of abnormal cells present.

I wish to thank the Cancer Research Council for financial support. Reprints not available.

\section{References}

Craig, L. C., Chen, H. C., and Taylor, W. I. (1969). Fournal of Macromolecular Science and Chemistry, part A, 3, 133.

Doré, J. F., et al. (1967). Lancet, 2, 1396.

Huehns, E. R. (1968). In Chromatographic and Electrophoretic Techniques, ed. Ivor Smith, 2nd edn., vol. 2. London, Heinemann.

Mathé, G. (1970). British Medical fournal, 4, 487.

Terasaki, P. J., and McClelland, J. D. (1964). Nature, 204, 998. 